Оксана БАБАКІНА,

orcid.org/0000-0001-6900-6513

кандидат педагогічних наук, доиент,

професор кафедри педагогіки, психології, початкової освіти

та освітнього менеджменту

Комунального закладу «Харківська гуманітарно-педагогічна академія»

Харківської обласної ради

(Харків, Украӥна) babakinaoksana0910@gmail.com

\title{
ОРГАНІЗАЦІЙНО-ПЕДАГОГІЧНІ ПЕРЕДУМОВИ РОЗВИТКУ СИСТЕМИ ПІДВИЩЕННЯ КВАЛІФІКАЦІЇ НАУКОВО-ПЕДАГОГІЧНИХ ПРАЦІВНИКІВ ЗАКЛАДІВ ВИЩОЇ ОСВІТИ В 50-70-ТІ РОКИ ХХ СТОЛІТТЯ
}

\begin{abstract}
У статті здійснено ретроспективний, історико-порівняльний, порівняльно-зіставний, хронологічний аналіз першоджерел, класифікацію та систематизацію теоретичних і статистичних даних щзодо виявлення організаиійно-педагогічних передумов розвитку системи підвищення кваліфікації науково-педагогічних пращівників закладів вищої освіти в 50-70-ті роки ХХ століття. 3'ясовано, щзо метою діяльності СПК керівних кадрів і НПП ЗВО СРСР у 50-70 роки ХХ століття було забезпечення освітніх установ висококваліфікованими педагогічними та науково-педагогічними кадрами, підвищення їхньої професійної кваліфікації та ідеологічно-політичного рівня. Усе вищесказане підтверджується історико-порівняльним і структурно-функиіональним аналізом нормативноправових документів розпорядчого характеру з проблеми вдосконалення СПК НПП із метою приведення ії нормативно-правової бази у відповідність із нагальними потребами розвитку суспільних процесів, науки $і$ техніки. Прогресивним етапом розвитку СПК НПП було прийняття 1956 року Постанови ЦК КПРС і РМ СРСР «Щодо вдосконалення підготовки та атестаиії наукових і педагогічних кадрів», в якій була введено норму обов 'язкової публікації результатів проведених досліджень у всесоюзних або республіканських спеціалізованих (відповідно до теми дослідження) виданнях. Аналіз нормативно-правових документів дозволив дійти висновку, щьо серед усіх організаційних структурних форм підготовки здобувачів учених ступенів головне місие у СПК НПП ЗВО займала аспірантура, як єдина цілеспрямована форма підвищення наукової кваліфікації НПП, організаџійно-правові основи якої регламентувалися відповідними положеннями про аспірантуру. Проаналізовано та виокремлено, щзо організаџійно-педагогічними передумовами розвитку системи підвищення кваліфікації науково-педагогічних працівників закладів вищої освіти в 50-70-ті роки ХХ століття можна вважати: розвиток аспірантури як організаиійної структурної форми СПК НПП ЗВО України; розширення мережі наукових установ, розвиток української науки, шьо зосереджувалася на вирішенні фундаментальних проблем; удосконалення нормативно-правової бази щчодо підвищення вимог до атестації НПП ЗВО у СПК Украӥни; появу нових організаџійних структурних форм у СПК НПП: інституту здобувачів наукових ступенів, прикомандирування докторантів, цільову аспірантуру.

Ключові слова: передумови розвитку, організаційно-педагогічні передумови, підвищення кваліфікації, науково-педагогічні працівники.
\end{abstract}

Oksana BABAKINA, orcid.org/0000-0001-6900-6513

Candidate of Pedagogical Sciences, Associate Professor, Professor at the Department of Pedagogy, Psychology, Primary Education and Education Management Municipal Establishment "Kharkiv Humanitarian Pedagogical Academy" of Kharkiv Regional Council (Kharkiv,Ukraine) babakinaoksana0910@gmail.com

\section{ORGANIZATIONAL AND PEDAGOGICAL PREREQUISITES FOR THE DEVELOPMENT OF THE PROFESSIONAL DEVELOPMENT SYSTEM OF HIGHER EDUCATION RESEARCH-TEACHING STAFF IN THE 50-70S OF THE TWENTIETH CENTURY}

The article provides a retrospective, historical-comparative, comparative-contrastive, and chronological analysis of primary literature, classification and systematization of theoretical and statistical data to identify organizational and pedagogical prerequisites for the development of professional development of higher education research-teaching staff in the 50-70s of the twentieth century. It was found that the purpose of the SPD of managerial personnel and RTS of HEI of the USSR in the 50-70 years of the twentieth century was to provide educational institutions with highly qualified teaching and research-teaching staff, the improving their professional skills and ideological and political level. 
All the above is confirmed by the historical-comparative and structural-functional analysis of regulatory documents of an administrative nature on the problem of improving the SPD of RTS to bring its regulatory framework in line with the urgent needs of social processes, science and technology. A progressive stage in the development of the PDS of RTS was the adoption in 1956 of the Resolution of the Central Committee of the CPSU and the CM of the USSR "On improving the training and certification of the research-teaching staff", which introduced a mandatory publication of research results in all-Union or national specialized publications. The analysis of normative-legal documents allowed to conclude that among all organizational structural forms of preparing applicants for a degree the main place in PDS of RTS of HEI was occupied by postgraduate study, as the only purposeful form of improvement of scientific qualification of RTS which organizational and legal bases were regulated by corresponding provisions on postgraduate study. It is analyzed and singled out that the organizational and pedagogical prerequisites for the development of the system of professional development of higher education research-teaching staff in the 50-the 70s of the twentieth century can be considered as: the development of the graduate school as an organizational structural form PDS of RTS of HEI; the expansion of the network of scientific institutions, the development of Ukrainian science, which focused on solving fundamental problems; improvement of the regulatory framework for increasing the requirements for certification of RTS of HEI in the PDS of Ukraine; the emergence of new organizational structural forms in PDS of RTS: institute of applicants for scientific degrees, secondment of doctoral students, targeted graduate school.

Key words: prerequisites for development, organizational and pedagogical prerequisites, research-teaching staff.

Постановка проблеми. Для здійснення грунтовного дослідження проблеми розвитку системи підвищення кваліфікації науково-педагогічних працівників закладів вищої освіти (далі - СПК НПП 3ВО) в 50-70-ті роки XX століття вважаємо доцільним проаналізувати організаційно-педагогічні передумови цього процесу.

Аналіз досліджень. Відповідно до специфіки історико-педагогічного дослідження його теоретичну основу становлять: положення теорії i методики педагогічної та післядипломної педагогічної освіти (А. Алексюк, К. Гораш, В. Луговий, В. Олійник, В. Паламарчук, О. Пєхота, Н. Протасова, Л. Пуховська, Т. Сущенко, М. Ярмаченко та ін.); концептуальні положення щодо підвищення кваліфікації педагогічних працівників у системі післядипломної педагогічної освіти (С. Антощук, В. Бондар, Г. Єльникова, Л. Даниленко, М. Красовицький, В. Маслов, В. Олійник, В. Пуцов, П. Худомінський та ін.); науково-методичні засади розвитку СПК педагогічних працівників у різні історичні періоди (Л. Безтелесна, Г. Додонова, І. Жорова, І. Зварич, В. Мороз, О. Петрик, А. Печенюк, Н. Чепурна та ін.).

Мета статті - проаналізувати та виокремити організаційно-педагогічні передумови розвитку системи підвищення кваліфікації науковопедагогічних працівників закладів вищої освіти в 50-70-ті роки XX століття.

Виклад основного матеріалу. Логіка нашого дослідження передбачає розкриття понять «передумови» та «передумови розвитку». У «Словнику української мови» передумова трактується як «попередня умова існування, виникнення, діяння i т. ін. чого-небудь». Сутність поняття «передумова» визначила зміст даного підрозділу відповідно до його завдання (Словник української мови, 1975: 178-179.).
Передумови розвитку - це сукупність природних та суспільних ресурсів і можливостей, здатних спричинити соціальний прогрес (Гавриленко, 2001).

Слушним для нас $\epsilon$ визначення $€$. Хрикова, О. Адаменко, В. Курила та інших: «Логіка розвитку педагогічної науки» характеризується такими складниками: спирання наукових досліджень на накопичені раніше знання; постановка наукових проблем, які зумовлюються попереднім розвитком науки; розвиток певних попередніх наукових ідей; відповідність розвитку педагогічної науки об'єктивним соціальним потребам виховання, а не ідеологічним чинникам» (Хриков, 2013: 113).

У монографії К. Галкіна «Вища освіта та підготовка наукових кадрів СРСР», що надрукована 1958 року, вперше здійснено грунтовний аналіз та наведено статичні дані щодо процесу становлення системи підготовки наукових кадрів у 1917-1925 рр.; доведено необхідність упровадження нових форм підготовки наукових кадрів, зокрема національних, та атестації наукових кадрів СРСР; висвітлено питання організації аспірантури (1925-1930 рр.), особливості іiі розвитку в післявоєнні роки (1941-1956 рр.), присудження наукових ступенів у нормативно-правових актах СРСР, а також здійснено аналіз наукових праць щодо теоретичних досліджень 3 історії їх підготовки (Галкін, 1958).

О. Сухомлинська стверджує: «50-70-ті роки $\mathrm{XX}$ століття принесли нові тенденції і якісні зміни в розвиток радянської освіти. Вища освіта була всередині цих змін і також почала трансформуватися і реформуватися. Після смерті Й. Сталіна ідеї політехнізації навчання знайшли нове життя, оскільки саме 3 ними пов'язували реформування всієї вітчизняної системи освіти. Важливу роль у цих процесах відіграла особистість М. Хрущова, який був справді налаштований на зміни. Підго- 
товку проєктів змін у сфері вищої освіти розпочали 3 прийняття постанов, у яких порушували актуальні питання подальшого розвитку вітчизняної освіти» (Сухомлинська, 2014: 18).

У 50-70-ті рр. ХХ століття організаційно-педагогічними передумовами розвитку СПК НПП ЗВО вважаємо такі.

1. Розвиток аспірантури як організачійноі структурної форми СПК НПП ЗВО Украӥни.

До цього часу підготовка аспірантів здійснювалася відповідно до «Положення про аспірантуру» 1939 року. Ця форма підвищення кваліфікації була на той час майже єдиним способом формування науково-педагогічного кадрового потенціалу країни, хоча підготовка аспірантів і мала певні недоліки: мета деяких програм підготовки була неактуальною, існував формальний підхід до написання індивідуальних навчальних планів, не приділялося належної уваги педагогічній практиці.

Вирішенню цієї проблеми сприяв наказ Міністерства вищої освіти від 17 лютого 1948 року «Про заходи щодо поліпшення підготовки науковопедагогічних кадрів через аспірантуру» (Справочник для поступающих в аспирантуру, 1948), у змісті якого визначалося незадовільне виконання плану прийому до аспірантури, значний відсів невстигаючих аспірантів, малоцінність у науковому відношенні тем дисертаційних робіт.

Наступним нормативно-правовим документом була Постанова Ради Міністрів СРСР від 22 травня 1948 року «Про підготовку науково-педагогічних і наукових кадрів через аспірантуру» (Аспирантура вузов СССР. Справочник, 1949). Прийняття цієі Постанови можна вважати точкою відліку встановлення централізованого планування і контролю над відтворенням НПП у межах загального народногосподарського плану, який затверджувався РМ СРСР. Уперше для випускників аспірантури цією Постановою введено зобов'язання відпрацювати три роки у ЗВО, установах і підприємствах за направленнями відповідних міністерств і відомств.

Також у цьому документі була прописана вимога до Міністерства вищої освіти СРСР розробити 3 урахуванням змін, які відбувалися в суспільстві, організаційно-правові умови підготовки аспірантів і затвердити нове положення про аспірантуру. Дане положення було затверджено 25 листопада 1950 року (Высшая школа. Основные постановления, 1957), в якому зазначено:

- загальне управління підготовкою науковопедагогічних кадрів в умовах аспірантури здійснює Міністерство вищої освіти СРСР;

- загальне управління підготовкою науковопедагогічних кадрів у науково-дослідних устано- вах АН СРСР і академіях наук союзних республік здійснює Президія АН СРСР;

- план та організаційно-методичні умови підготовки аспірантів в усіх відповідних закладах встановлено єдиними;

- право зарахування та затвердження атестаційних звітів аспірантів передано вищезазначеним центральним адміністративним органам (Міністерству вищої освіти СРСР і Президії АН СРСР).

Однак дане право в подальшому зарекомендувало себе як занадто бюрократизоване і було скасовано.

2. Розширення мережі наукових установ, розвиток украӥнської науки, щзо зосереджувалася на виріменні фундаментальних проблем.

Розвитку української науки загалом та СПК НПП ЗВО України сприяло збільшення наукових, науково-дослідних установ. «До складу АН УРСР на кінець 50-х років входило 36 науководослідних інститутів і 19 інших наукових установ». У 1957 р. Україну було прийнято до Міжнародного агентства 3 атомної енергії (МАГАТЕ)» (Україна у 50-60 роках 20 століття).

Відбувалися зміни в СПК НПП у галузі педагогічних наук. 1955 року згідно з постановою Ради Міністрів УРСР № 47 від 4 січня 1955 р. і наказів Міносвіти УРСР № 16 від 14 січня 1955 р. та № 22 від 21 січня 1955 р. Український науково-дослідний інститут педагогіки було перейменовано в Науково-дослідний інститут педагогіки Української РСР (НДІП УРСР) (ЦГАОР УССР. Ф. 5127. Оп. 1. Д. 198). Відповідно до Статуту НДІП УРСР, затвердженого Міносвіти УРСР у 1960 році, основними завданнями визначено розвиток педагогічної науки, сприяння розвитку народної освіти в республіці; підготовку науково-педагогічних кадрів 3 наукових педагогічних спеціальностей тощо (ЦГАОР УССР. Ф. 5127. Оп. 1. Д. 551).

Метою діяльності СПК керівних кадрів і НПП ЗВО СРСР у 50-70 роки ХХ століття було забезпечення освітніх установ висококваліфікованими педагогічними та науково-педагогічними кадрами, підвищення їхньої професійної кваліфікації та ідеологічно-політичного рівня. Цьому сприяло: створення Центрального інституту вдосконалення вчителів як головного науково-методичного центру Міністерства освіти УРСР з питань післядипломної освіти та обласних інститутів удосконалення вчителів як науково-методичних центрів галузі в регіонах; розвиток заочної форми післядипломної педагогічної освіти та осучаснення таких форм післядипломної педагогічної освіти, як: курси (очні та заочні) підвищення кваліфікації, педагогічні та науково-педагогічні конференції 
тощо; введення вимоги обов' язкового підвищення кваліфікації педагогічних працівників через кожні п’ять років.

У досліджуваних хронологічних межах наукові доробки видатних українських учених були високо оцінені - присуджено Нобелівські премії: «Семен Кузнець (1901-1985) - навчався у Харкові. У 1971 р. «за емпірично обгрунтоване тлумачення економічного зростання, яке привело до нового, глибшого розуміння як економічної та соціальної структур, так і процесу розвитку» йому було присуджено Нобелівську премію з економіки; Роалд Гоффман (народився в 1937 р.) - народився в Золочеві, лауреат Нобелівської премії «за розробку теорії протікання хімічних реакцій», що значно розширює можливості для планування хімічних експериментів. Саме йому належать слова «Україно, обітована земле мого серця!»; Ігор Тамм (1895-1971) - дитинство і юність пройшли в Слисаветграді (зараз - Кропивницький), де вчений закінчив гімназію; викладав у Одеському політехнічному університеті та у Таврійському університеті, в якому також навчався. Отримав Нобелівську премію в галузі фізики 1958 року разом із Іллею Франком та Павлом Черенковим «за відкриття i тлумачення ефекту Вавілова - Черенкова»; Лев Ландау (1908-1968) - викладав та проводив наукові дослідження в Українському фізико-технічному інституті, Харківському університеті та Харківському політехнічному інституті, де зробив низку відкриттів у галузі фізики. Отримав Нобелівську премію 1962 року «за піонерські теорії конденсованих середовищ, особливо теорії рідкого гелію» (Нобелівські лауреати - вихідці з України).

Певні позитивні зміни спостерігалися і в динаміці підготовки наукових кадрів у СПК: «1950 року в АН УРСР, який був головним науковим закладом України, працював 51 дійсний член і 55 членів-кореспондентів АН УРСР. Із 1359 наукових співробітників Академії 185 осіб були докторами і 627 - кандидатами наук (Історія Академії наук Української РСР, 1967). Вони брали участь у підготовці наукових кадрів, i, зокрема, лише в інститутах АН УРСР 1950 року було захищено 7 докторських і 53 кандидатських дисертації (Сидорчук 1998: 13). У 1958-1965 рр. кількість науковців збільшилась із 37 до 94 тис. осіб (Україна у 50-60 роках 20 століття).

3. Удосконалення нормативно-правової бази щуодо підвищення вимог до атестаиії НПП ЗВО у СПК Украӥни.

Усе вищесказане підтверджується історикопорівняльним та структурно-функціональним аналізом нормативно-правових документів розпо- рядчого характеру з проблеми вдосконалення СПК НПП із метою приведення іiї нормативно-правової бази у відповідність із нагальними потребами розвитку суспільних процесів, науки і техніки: «Про заходи щодо поліпшення підготовки й атестації наукових і педагогічних кадрів» від 20 серпня 1956 року; «Про заходи щодо поліпшення якості дисертаційних робіт і порядок присудження вчених ступенів і звань» від 24 січня 1960 року; «Про заходи щодо поліпшення підготовки наукових і науково-педагогічних кадрів» від 13 червня 1961 року; «Про заходи щодо подальшого поліпшення підбору і підготовки наукових кадрів» від 12 травня 1962 року; «Про поліпшення підготовки наукових і науково-педагогічних кадрів» від 16 листопада 1967 року.

Вивчення цих документів показало, що першочерговим завданням, яке уряд надав керівництвам президій академії наук і ВАК при Міністерстві вищої і середньої спеціальної освіти СРСР, наукових установ, ЗВО, було підвищення вимог до атестації НПК, у тому числі через підвищення якості захищених дисертаційних робіт. При цьому наголошувалося, що написання дисертаційного дослідження має бути не самоціллю, а логічним завершенням наукових досліджень.

Прогресивним етапом розвитку СПК НПП було прийняття в 1956 році Постанови ЦК КПРС і РМ СРСР «Щодо вдосконалення підготовки та атестації наукових і педагогічних кадрів», в якій була введена норма обов'язкової публікації результатів проведених досліджень у всесоюзних або республіканських спеціалізованих (відповідно до теми дослідження) виданнях. А також на кожну дисертаційну роботу, крім відгуків офіційних опонентів, уведено відгук провідної організації (Аспирантура: справочник, 1963).

У 1967 році з метою підвищення якості та поширення інформації щодо захищених дисертаційних робіт, запобігання плагіату, уникнення дублювання тем наукових досліджень була введена обов' язкова вимога надання до Державного комітету РМ СРСР $з$ науки і техніки мікрофільмування захищених дисертацій.

В «Інструкціях щодо порядку присудження вчених ступенів та присвоєння вчених звань» 1960, 1966 років та «Положенні щодо порядку присудження вчених ступенів та присвоєння вчених звань» 1975 року пропонувалося вчені ступені присуджувати лише за роботи, які мали науковотеоретичне і практичне значення, містили новизну результатів дослідження, а також обов'язково мали бути опубліковані за період навчання в аспірантурі в методичних підручниках, посібниках тощо. Кри- 
терієм відповідності наукової роботи на здобуття наукового ступеня доктора наук було наявність теоретичного узагальнення й наукового обгрунтування шляхів вирішення значної наукової проблеми, що представляла вагомий внесок у розвиток теоретичної науки та його практичного втілення (Инструкция о порядке присуждения ученых степеней, 1960).

Посиленню вимог до атестації НПП ЗВО у СПК України сприяло створення в 1974 р. спеціалізованих рад, які формувалися з числа найбільш авторитетних науковців відповідної спеціальності.

4. Поява нових організачійних структурних форм у СПК НПП: інститут здобувачів наукових ступенів, прикомандирування докторантів. цільова аспірантура.

До значущих організаційно-педагогічних передумов розвитку СПК НПП ЗВО України в останній чверті XX - на початку XXI століття відносимо створення у 50-70-х роках XX століття нових організаційних структурних форм підвищення кваліфікації науково-педагогічних кадрів: інституту здобувачів наукових ступенів, прикомандирування докторантів, цільової аспірантури.

Наприкінці 50-х років на виконання Постанови РМ СРСР від 4 листопада 1947 року «Про підготовку наукових кадрів вищої кваліфікації» організовуються інститути здобувачів наукових ступенів не тільки для викладацького складу, а й працівників інших галузей.

Поряд із підготовкою здобувачів наукових ступенів держава приділяла увагу й підготовці науково-педагогічних кадрів вищої кваліфікації через створення інститутів прикомандирування науковців країни для завершення роботи над докторськими дисертаціями терміном до двох років. Однак в 1956 р. ці інститути були скасовані через їх недоцільність, а їхні обов'язки поклалися на НПП, які бажали підвищити власний рівень наукової кваліфікації через написання докторських наукових робіт у режимі самоосвіти шляхом участі в науково-дослідній роботі 3ВО, наукових установ, у промислових і господарських підприємствах. Докторантура як форма підвищення кваліфікації НПП була відновлена в 1988 році.

Також одним із рушійних чинників розвитку даної системи в зазначений період (50-70-ті роки XX століття) вважаємо надання можливості здобувачам учених ступенів прикріплюватися до відповідних кафедр, структурних підрозділів і лабораторій та під керівництвом провідних фахівців самостійно (поза межами аспірантури) працювати над власним науковим доробком.

Для поліпшення підготовки та підвищення кваліфікації НПП вищої школи у 60-ті роки XX сто- ліття було введено посади «стажер-дослідник» та «стажер-викладач». А починаючи з 1967 року, в спеціалізованих 3ВО в галузі мистецтва та культури введено дворічну асистентуру-стажування для обдарованих кадрів за виконавчими та педагогічно-мистецькими спеціальностями.

Аналіз нормативно-правових документів дозволив дійти висновку, що серед усіх організаційних структурних форм підготовки здобувачів учених ступенів головне місце у СПК НПП ЗВО займала аспірантура, як єдина цілеспрямована форма підвищення наукової кваліфікації НПП, організаційно-правові основи якої регламентувалися відповідними положеннями про аспірантуру.

У 1961 році, спираючись на установку партії щодо поліпшення якості НПП народногосподарських галузей та його збільшення, Постановою ЦК КПРС та РМ СРСР «Про міри покращення підготовки наукових i науково-педагогічних кадрів» було започатковано організацію цільових аспірантур (Аспирантура: справочник, 1971). Це сприяло зростанню кількості захищених дисертації на здобуття вчених ступенів кандидатів наук або докторів наук за різними спеціальностями, однак і негативно вплинуло на їхні якісні характеристики, оскільки здебільшого не враховувалися потреби регіонів, не проводився грунтовний аналіз тематик дисертаційних досліджень, при цьому здійснювався контроль (командно-адміністративний) за планом вступу та випуску.

3 метою підвищення якості аспірантури 3 1967 року переважне (першочергове) право на зарахування до аспірантури надавалося здобувачам, які вже здали кандидатські іспити.

3 метою забезпечення актуальності, відповідності вимогам сучасності та якості написання дисертаційних робіт у 1960 році при НДІП УРСР було створено Республіканську раду 3 координації наукової діяльності в галузі педагогічних наук, до складу якого включені всі завідувачі кафедр педагогіки і психології ЗВО України. А також для систематизації та координації тематики науководослідних робіт було затверджено номенклатуру спеціальностей підготовки за галузями наук в аспірантурах, як очної так і заочної форм навчання, у ЗВО та науково-дослідних інститутах СРСР.

С. Кононова наводить такі статичні дані: «У 50-60-ті роки було затверджено 89 наукових спеціальностей. Кількісна динаміка затвердження спеціальностей за роками виглядає так: 1953 року9; 1957 року - 27; 1962 року - 7; 1963 року - 7 (Кононова, 2009: 62). Зокрема, в галузі педагогіки і психології це: у 1953 р.: дошкільна педагогіка; методика викладання предметів (за переліком); 
педагогіка, історія педагогіки; психологія; теорія і методика фізичного виховання; спеціальна педагогіка (тифлопедагогіка, сурдопедагогіка й олігофренопедагогіка, логопедія); спеціальна психологія (психологія сліпих, глухонімих і розумово відсталих дітей); у 1957 р.: методика викладання предметів (із зазначенням кожного); педагогіка; спеціальна педагогіка; спеціальна психологія; теорія і методика фізичного виховання і спортивного тренування тощо (Кононова, 2009).

Порівняльно-історичний аналіз проблеми підготовки фахівців вищої кваліфікації в умовах аспірантури, а також висвітлення СПК НПП здійснено у відомих працях того часу, присвячених 50-річчю Жовтневої революції: «Історія Академії наук Української РСР» (1967р.) та «Розвиток науки в Українській РСР за 40 років» (1967р.). Однак, ураховуючи ідеологічний напрям того часу та вплив комуністичної партії, дані видання відрізнялись «тенденційністю добору та інтерпретації матеріалу, парадно-ювілейним стилем його викладення, політизацією історії науки, недооцінкою дореволюційного потенціалу науково-педагогічних кадрів» (Регейло, 2010).

Також для з'ясування організаційно-педагогічних передумов розвитку СПК НПП ЗВО в останній чверті XX - на початку XXI століття проаналізовано науковий доробок «Підбір, підготовка та атестація наукових кадрів СРСР. Це питання історії та правового регулювання» колективу авторів Г. Доброва, В. Чуткерашвілі, Б. Лебіна (Лебин, 1966), в якому вони вивчили й узагальнили історичні умови, що склалися на всіх етапах розвитку радянської держави; визначили основні принципи підбору, підготовки та атестації наукових кадрів у СРСР, здійснили аналіз чинного законодавства iз зазначених питань 3 метою правильного розуміння сформованих правовідносин науковців у СРСР; висвітлили порядок правового регулювання підготовки і встановлення кваліфікації працівників науки в інших країнах соціалізму. Цінною, на наш погляд, є розробка рекомендацій щодо забезпечення формування кадрів наукової інтелігенції та порушення питання необхідності підготовки наукових кадрів у системі АН СРСР та її республіканських відділеннях. На жаль, відомості щодо діяльності кожного із зазначених відділень загалом та АН УРСР зокрема відсутні.

Отже, в цілому в 50-70-ті роки XX століття простежується тенденція збільшення кількості педагогічних i психологічних спеціальностей в аспірантурі. Підсумовуючи все проаналізоване вище, вважаємо доведеним, що підготовка та підвищення кваліфікації НПП здійснюва- лася виключно на підставі нормативно-правових документів, затверджених ЦК КПРС, РМ СРСР та МВО СРСР та УРСР, а саме постанови щодо: покращення якості підготовки наукових і науково-педагогічних кадрів (1956, 1960-1963, 1967 років), діяльності аспірантури, організації та роботи нових організаційних форм підвищення кваліфікації науково-педагогічних кадрів (інститути здобувачів наукових ступенів, прикомандирування докторантів тощо); положення та інструктивні листи щодо порядку присудження наукових ступенів і надання вчених звань (1957, 1960, 1966, 1967 років) тощо.

Висновки. Таким чином, організаційно-педагогічними передумовами розвитку системи підвищення кваліфікації науково-педагогічних працівників закладів вищої освіти в 50-70-ті роки $\mathrm{XX}$ століття можна вважати: 1) розвиток аспірантури як організаційної структурної форми СПК НПП ЗВО України; 2) розширення мережі наукових установ, розвиток української науки, що зосереджувалася на вирішенні фундаментальних проблем; 3 ) удосконалення нормативноправової бази щодо підвищення вимог до атестації НПП ЗВО у СПК України; 4) появу нових організаційних структурних форм у СПК НПП: інституту здобувачів наукових ступенів, прикомандирування докторантів. цільової аспірантури. Ознайомлення з вищеперерахованими передумовами дозволило дійти висновку, що для вирішення існуючих на той час проблем і недоліків (низька якість захищених дисертаційних робіт, відсутність їхньої практичної та теоретичної значущості $\mathrm{i}$, як наслідок, - низький рівень підготовленості до самостійної подальшої науково-дослідної та науково-педагогічної робіти; невиконання планів підготовки та підвищення кваліфікації НПК, відсутність тем дисертаційних досліджень або недостатнє їх охоплення актуальних галузей науки (фізики, математики, біохімії, біофізики, аеродинаміки, радіотехніки, електроніки тощо, в той час за гуманітарним напрямом підготовка аспірантів перевищувала потребу в цих кадрах); обмежена кількість бюджетних місць; незадовільне матеріально-технічне забезпечення освітнього процесу; недостатня кількість у наукових установах i ЗВО НПП з науковим ступенем та званням (кандидатів та докторів наук, доцентів і професорів); низький рівень фахової компетентності вступників (більшість вступників - випускники ЗВО, які не мали досвіду практичної роботи) тощо) було прийнято низку нормативно-правових документів, метою яких було покращення якості підвищення кваліфікації НПП. 


\section{СПИСОК ВИКОРИСТАНИХ ДЖЕРЕЛ}

1. Гавриленко І. М. Соціальний розвиток : навч. посібник. Ірпінь : Акад. ДПС України, 2001. 484 с.

2. Галкин К. Т. Высшее образование и подготовка научных кадров в СССР. Москва : Сов. наука, 1958. 175 с.

3. Инструкция о порядке присуждения ученых степеней и присвоения ученых званий. Москва : ВАК, 1960. 33 с.

4. Історія Академії наук Української РСР : в 2 ч. Київ : Головн. ред. Укр. рад. енц. АН УРСР, 1967. 187 с.

5. Кононова С. В. История развития научных педагогических специальностей в России (1934-2001 гг.). Научнотеоретический журнал «Научные проблемы гуманитарных исследований». 2009. Вып. 4 (2). С. 59-63.

6. Лебин Б. Д. Подбор, подготовка и аттестация научных кадров в СССР. Вопросы истории и правового регулирования. Москва, Ленинград : Наука, 1966. 288 с.

7. Методологічні засади педагогічного дослідження : монографія / за заг. ред. В. С. Курила, С. М. Хрикова ; Держ. закл. «Луган. нац. ун-т імені Тараса Шевченка». Луганськ : Вид-во ДЗ «ЛНУ імені Тараса Шевченка», 2013.248 с.

8. Нобелівські лауреати - вихідці з України. URL: https://cutt.ly/xf6DPXу

9. Постановление СМ СССР от 22.05.1948 г. № 1709 «О подготовке научно-педагогических и научных кадров через аспирантуру». Аспирантура вузов СССР. Справочник. Москва : Советская наука, 1949. С. 1-2.

10. Постановление ЦК КПСС и СМ СССР от 13.06.1961 г. № 536 «О мерах по улучшению подготовки научных и научно-педагогических кадров». Аспирантура: справочник для поступающих в аспирантуру и соискателей ученых степеней. Москва : Советская наука», 1971. С. 12-13.

11. Постановление ЦК КПСС и СМ СССР от 20.08.1956 г. № 1174 «О мерах по улучшению подготовки и аттестации научных и педагогических кадров». Аспирантура: справочник для поступаюших в аспирантуру и соискателей ученых степеней. Москва : Советская наука, 1963. С. 10-11.

12. Приказ министра высшего образования СССР от 17.02 .1948 г. № 202 «О мерах по улучшению подготовки научно-педагогических кадров через аспирантуру». Справочник для поступающих в аспирантуру юридических институтов. Москва, 1948. С. 27-28.

13. Приложение № 1 к приказу министра высшего образования СССР от 25.11.1950 г. № 2074 «Положение об аспирантуре при высших учебных заведениях и научно-исследовательских учреждениях». Высшая школа. Основные постановления, приказы и инструкциии / под ред. Л. И. Карпова, В. А. Северцева. Москва : Советская наука, 1957. С. 280-281.

14. Регейло I. Ю. Підготовка наукових і науково-педагогічних кадрів вищої кваліфікації в Україні у XX - початку XXI століття: історіографічні аспекти. Педагогічний дискурс. 2010. Вип. 7. С. 189-194.

15. Сидорчук Т. Г. Підготовка наукових та науково-педагогічних кадрів через аспірантуру в Україні (1920-і 1970-і роки) : автореф. дис. ... канд. істор. наук : 07.00.01. Запоріжжя, 1998. 20 с.

16. Словник української мови: в 11 томах. 1975. Том 6. С. 178-179.

17. Сухомлинська О. В. Радянська педагогіка як ідеологія: спроба історичної реконструкції. Історико-педагогічний альманах. 2014. № 1. С. 4-24.

18. Україна у 50-60 роках 20 століття. URL: https://osvita.ua/vnz/reports/history/35682/

19. ЦГАОР УССР. Ф. 5127. ОП. 1. Д. 551. Л. 1-12.

20. ЦГАОР УССР. Ф. 5127. Оп. 1. Д. 198. Л. 23-24.

\section{REFERENCES}

1. Gavrilenko I. M. SotsIalniy rozvitok [Social development] : navch. posIb. IrpIn : Akad. DPS UkraYini, 2001.484 s. [in Ukrainian].

2. Galkin K. T. Vyisshee obrazovanie i podgotovka nauchnyih kadrov v SSSR. [Higher education and training of scientific personnel in the USSR]. M.: Sov. nauka, 1958. 175 s. [in Russian].

3. Instruktsiya o poryadke prisuzhdeniya uchenyih stepeney i prisvoeniya uchenyih zvaniy. [The instruction about the order of awarding degrees and awarding academic titles]. M.: VAK, 1960. $33 \mathrm{~s}$. [in Russian].

4. Istorlya AkademIYi nauk UkraYinskoYi RSR [History of the Academy of Sciences of the Ukrainian SSR] : v 2 ch. K. : Golovn. red. Ukr. rad. ents. AN URSR. 1967. 187 s. [in Ukrainian].

5. Kononova S. V. Istoriya razvitiya nauchnyih pedagogicheskih spetsialnostey v Rossii (1934-2001 gg.). [History of the development of scientific pedagogical specialties in Russia (1934-2001)]. Nauchno-teoreticheskiy zhurnal «Nauchnyie problemyi gumanitarnyih issledovaniy». Vyip. 4 (2). 2009. S. 59-63. [in Russian].

6. Lebin B.D. Podbor, podgotovka i attestatsiya nauchnyih kadrov v SSSR. [Selection, training and certification of scientific personnel in the USSR]. Voprosyi istorii i pravovogo regulirovaniya. M., L.: Nauka, 1966. 288 s. [in Russian].

7. MetodologIchnI zasadi pedagogIchnogo doslIdzhennya [Methodological foundations of pedagogical research] : monograflya / za zag. red. V. S. Kurila, E. M. Hrikova ; Derzh. zakl. «Lugan. nats. un-t ImenI Tarasa Shevchenka». Lugansk: Vid-vo DZ «LNU ImenI Tarasa Shevchenka», 2013. 248 s. [in Ukrainian].

8. NobelIvskI laureati — vihIdtsI z UkraYini. [Nobel laureates come from Ukraine]. URL: https://cutt.ly/xf6DPXy. [in Ukrainian].

9. Postanovlenie SM SSSR ot 22.05.1948 \# 1709 «O podgotovke nauchno-pedagogicheskih i nauchnyih kadrov cherez aspiranturu». [Resolution of the CM of the USSR of 22.05.1948 No. 1709 "On training of scientific, pedagogical and scientific personnel through postgraduate studies"]. Aspirantura vuzov SSSR. Spravochnik. M.: Sovetskaya nauka, 1949. S. 1-2. [in Russian].

10. Postanovlenie TsK KPSS i SM SSSR ot 13.06.1961 \# 536 «O merah po uluchsheniyu podgotovki nauchnyih $\mathrm{i}$ nauchno-pedagogicheskih kadrov». [Resolution of the Central Committee of the CPSU and CM of the USSR of 13.06.1961 
No. 536 "On measures to improve the training of scientific and pedagogical personnel"]. Aspirantura: spravochnik dlya postupayuschih v aspiranturu i soiskateley uchenyih stepeney. M.: Sovetskaya nauka», 1971. S. 12-13. [in Russian].

11. Postanovlenie TsK KPSS i SM SSSR ot 20.08.1956 \# 1174 «O merah po uluchsheniyu podgotovki i attestatsii nauchnyih i pedagogicheskih kadrov». [Resolution of the Central Committee of the CPSU and CM of the USSR of 20.08.1956 No. 1174 "On measures to improve the training and certification of scientific and pedagogical personnel"]. Aspirantura: spravochnik dlya postupayuschih v aspiranturu i soiskateley uchenyih stepeney. M.: Sovetskaya nauka, 1963. S. 10-11. [in Russian].

12. Prikaz ministra vyisshego obrazovaniya SSSR ot 17.02 .1948 \# 202 «O merah po uluchsheniyu podgotovki nauchno-pedagogicheskih kadrov cherez aspiranturu». [Order of the minister of higher education of the USSR dated 17.02.1948 No. 202 "On measures to improve the training of scientific and pedagogical personnel through postgraduate studies"]. Spravochnik dlya postupayuschih v aspiranturu yuridicheskih institutov. M., 1948. S. 27-28. [in Russian].

13. Prilozhenie \# $1 \mathrm{k}$ prikazu ministra vyisshego obrazovaniya SSSR ot 25.11.1950 \# 2074 «Polozhenie ob aspiranture pri vyisshih uchebnyih zavedeniyah i nauchno-issledovatelskih uchrezhdeniyah». [Appendix No. 1 to the order of the minister of higher education of the USSR dated 25.11.1950 No. 2074 "Regulations on postgraduate studies at higher educational institutions and research institutions"]. Vyisshaya shkola. Osnovnyie postanovleniya, prikazyi i instruktsii / pod red. L. I. Karpova, V. A. Severtseva. M.: Sovetskaya nauka, 1957. S. 280-281. [in Russian].

14. Regeylo I. Yu. PIdgotovka naukovih I naukovo-pedagogIchnih kadrIv vischoYi kvalIfIkatsIYi v UkraYinI u HH pochatku HHI stolIttya: IstorIografIchnI aspekti. [Training of scientific and scientific-pedagogical personnel of higher qualification in Ukraine in the XX - beginning of the XXI century: historiographical aspects]. PedagogIchniy diskurs. 2010. Vip. 7. S. 189-194. [in Ukrainian].

15. Sidorchuk T. G. PIdgotovka naukovih ta naukovo-pedagogIchnih kadrIv cherez aspIranturu v UkraYinI(1920-I-1970-I roki) [Training of scientific and scientific-pedagogical personnel through postgraduate studies in Ukraine (1920s-1970s)] : avtoref. dis. ... kand. Istor. nauk : 07.00.01. ZaporIzhzhya. 1998. 20 s. [in Ukrainian].

16. Slovnik ukraYinskoYi movi [Dictionary of the Ukrainian language] : v 11 tomah. Tom 6, 1975. S. 178-179. [in Ukrainian].

17. Suhomlinska O. V. Radyanska pedagogika yak ideologiya: sproba istorichnoyi rekonstruktsiyi. [Sovetskaya pedagogika Kak ideologiya: attempted historical reconstruction.]. Istoriko-pedagogIchniy almanah. 2014. \# 1. S. 4-24. [in Ukrainian].

18. UkraYina u 50-60 rokah 20 stollttya. [Ukraine in 50-60 r. 20 st.]. URL: https://osvita.ua/vnz/reports/history/35682/. [in Ukrainian].

19. TsGAOR USSR. [CGAOR USSR]. F. 5127. Op. 1. D. 551. L. 1-12. [in Ukrainian].

20. TsGAOR USSR. [CGAOR USSR]. F. 5127. Op.1. D. 198. L. 23-24. [in Ukrainian]. 